\title{
Effects of novel polyether ionophore hainanmycin on nutrient digestion, metabolism and ruminal characteristics of goats
}

\author{
Ren Mingqiang, Shen Zanming, Zhao Ruqian, Lu Tianshui \\ and Chen Jie
}

\author{
Laboratory of Animal Physiology and Biochemistry, \\ Nanjing Agricultural University \\ Nanjing 210095. P. R. China
}

(Received 7 November 1997; accepted 14 January 1998)

\begin{abstract}
Five castrated male goats (average BW $21.3 \mathrm{~kg}$ ) with cannulae in the rumen and proximal duodenum were used to study the influence of intraruminal infusion of the polyether ionophore, hainanmycin $\left(0.05 \mathrm{mg} \mathrm{kg}^{-1} \mathrm{BW}\right.$ day-1$\left.^{-1}\right)$, on rumen characteristics and total tract digestion. Infused hainanmycin did not affect total volatile fatty acid (VFA) concentrations in the rumen, but increased $(\mathrm{P}<0.05)$ the molar proportions of propionate from 21.8 to $26.3 \%$ and decreased $(\mathrm{P}<0.05)$ that of acetate from 72.8 to $68.8 \%$. The ratio of acetate to propionate significantly declined $(\mathrm{P}<0.01)$ in the experimental period. Ruminal and duodenal chyme ammonia $\mathrm{N}\left(\mathrm{NH}_{3}-\mathrm{N}\right)$ levels were reduced $(\mathrm{P}<0.05) 39.5$ and $16.0 \%$, respectively, and the chyme urea- $\mathrm{N}$ concentration was reduced $(\mathrm{P}<0.05)$ $56.8 \%$ compared to the control. Infusion of hainanmycin had no effect $(\mathrm{P}>0.05)$ on apparent digestibility of dry matter (DM), organic matter (OM) or acid detergent fibre (ADF) in comparison with the control, but apparent nitrogen $(\mathrm{N})$ digestibility was markedly increased $(\mathrm{P}<0.05)$ from 46.1 to $56.4 \%$ in the hainanmycin infused period.
\end{abstract}

KEY WORDS: ionophore, hainanmycin, volatile fatty acid, ammonia nitrogen, rumen, goat

\section{INTRODUCTION}

The ionophore hainanmycin is a relatively new carboxylic ionophore produced by a strain of Streptomvces albus in soil. It is a monocarboxylic acid ionophore with a cation selectivity in the order of $\mathrm{Li}^{+}>\mathrm{Na}>>\mathrm{K}^{+}$. Like other ionophores, hainanmycin is highly effective against gram-positive bacteria, but it is ineffective against 
gram-negative bacteria and fungi. Polyether ionophores like monensin and salinomycin are widely used as feed additives in animal diets, they are used not only for the control of growth but for improvement of feed efficiency (Chalupa, 1984; Russel et al., 1989; Martini et al., 1996).

Our preliminary trial in vitro (Ren et al., 1996) has shown the ionophore hainanmycin to be effective in decreasing the ratio of acetate to propionate and $\mathrm{NH}_{3}-\mathrm{N}$ concentration in media. However, the effect of hainanmycin on ruminal fermentation characteristics in vivo has not been reported. The purpose of this investigation in goats was to evaluate quantitatively: 1. the ability of hainanmycin to alter ruminal fermentation characteristics, 2 . microbial synthesis and related efficiency and 3 . the effect of hainanmycin on digestion of DM, OM, ADF and $\mathrm{N}$ in vivo.

\section{MATERIAL AND METHODS}

\section{Animals}

Five adult castrated male local goats, $21.3 \mathrm{~kg}$ average body weight, were equipped with a ruminal cannula and a duodenal cannula which were placed between the pyloric and Oddi sphincters. The goats were housed individually in stalls under natural lighting, fed at 8.00 and $20.00 \mathrm{~h}$ daily with ad libitum hay (DM, 92.25\%; crude protein, $5.33 \%$ ) and free access to water.

\section{Experimental design}

The experiment was divided into two successive periods, 3 weeks each, in the experimental period the ionophore hainanmycin (from the Shanghai Institute of Pharmacology, Chinese Academy of Sciences) dissolved in a solution of ethanol and water $(1: 3, \mathrm{v} / \mathrm{v})$ was infused through the ruminal cannulae twice daily at 8.00 and $20.00 \mathrm{~h}$ at a rate proportional to the body weight of the goat $\left(0.05 \mathrm{mg} \mathrm{kg}^{-1} \mathrm{BW} /\right.$ day $^{-1}$ ). The infusion was maintained continuously throughout the experiment. Animals in the control period were infused with the same mixture of ethanol and water. At 8.00 and $20.00 \mathrm{~h}$ from day 12 to the end of each period, every animal was infused intraruminally with $20 \mathrm{ml}$ solution of chromium-ethylenediaminetetraacetate (Cr-EDTA, containing $\mathrm{Cr}^{2} \cdot 9.070 \mathrm{mg} / \mathrm{ml}$ ) to determine ruminal duodenal flow rate. Ruminal samples $(10-15 \mathrm{ml})$ were taken through the rumen cannulae at $0,2,4,6,8$ and $10 \mathrm{~h}$ after the morning feeding on day 15,18 and 21 of each period.

The duodenal chyme samples $(15-20 \mathrm{ml})$ were collected at $4 \mathrm{~h}$ intervals on day 15,18 and 21 of each period. The total faeces and grab samples of hay were stored at $-30^{\circ} \mathrm{C}$ until analyzed. 


\section{Analysis and calculations}

Ruminal VFA was analyzed on a Shimadzu GC-9A gas chromatograph by the method of Qin Weilin (1982), ruminal and duodenal chyme $\mathrm{NH}_{3}-\mathrm{N}$ by the phenolhypochloric method (Chancy and Marbach, 1962), the microbial protein-N (MCP-N) was assayed as described by Makkar et al. (1982). Dry matter of hay, chyme and facces was determined by heating the samples at $80^{\circ} \mathrm{C}$ for $48 \mathrm{~h}$ and ash content by heating at $550^{\circ} \mathrm{C}$ for $5 \mathrm{~h}$. Nitrogen was analyzed in fresh samples by means of an automated Tecator 1030 system. Feed and faeces were analyzed for ADF using the procedure of Van Soest (1970). Organic matter fermented in the rumen was considered equal to OM intake minus the difference between the amount of total $\mathrm{OM}$ reaching the duodenum and microbial organic matter reaching the duodenum. Feed $\mathrm{N}$ escaped to the small intestine was considered equal to total non-ammonia $\mathrm{N}$ leaving the abomasum minus MCP-N and, thus, included any endogenous contributions. $\mathrm{Cr}^{2+}$ concentration in duodenum was detected by atomic absorption spectrophotometry (model Hitachi 180-80) and chyme flows of duodenum were calculated as described by El-Shazly et al. (1976).

Data were analyzed by Statistica Software for Windows Release V4.5 (Stat Soft Inc., 1993).

\section{RESULTS AND DISCUSSION}

\section{Volatile fatty acid, ammonia- $N$ and microbial protein- $N$ in rumen fluid}

Total VFA concentration in ruminal fluid was not affected evidently by treatment, but concentration and molar proportions of individual VFA, however, were altered by infusing hainanmycin (Table 1). A shift was observed towards increased $(\mathrm{P}<0.05)$ proportions of propionate and decreased $(\mathrm{P}<0.05)$ proportions of acetate. Ruminal acetate concentration was lower in experimental than in control animals $(\mathrm{P}<0.05)$ during the whole $10 \mathrm{~h}$ period after morning feeding, conversely, the propionate level was higher in experimental animals $(\mathrm{P}<0.05)$. These results are similar to our experiment in vitro (Ren et al., 1996), and to those on other ionophore antibiotics (Chalupa, 1984; Lana and Russell, 1997). Such shifts toward increased production of propionate and decreased acetate imply increased recovery of energy contained in the fermentable substrate in forms that can be metabolized by the host animal. Studies have indicated some definite changes in rumen microbial populations and/or microbial metabolism in response to monensin (Russell and Strobel, 1989). Monensin has been found to be a metabolic inhibitor of hydrogen-producing and formate-producing bacteria, but was a stimulator for succinate-producing and propionate-producing bacteria (Chen and Wolin, 1978). The net effect of these influences would enhance propionate production at the expense of acetate production. 
TABLE 1

Rumen fluid characteristic in goats infused ruminally hainanmycin ${ }^{1}$

\begin{tabular}{lccc}
\hline & \multicolumn{2}{c}{ Period } & \\
\cline { 2 - 3 } Item & control & experimental & SE $^{\mathrm{b}}$ \\
\hline Total VFA, mmol & 56.46 & 53.32 & 6.95 \\
Acetate, mmol & $41.09^{\mathrm{a}}$ & $36.69^{\mathrm{b}}$ & 2.64 \\
Propionate, mmol & $12.33^{\mathrm{a}}$ & $14.04^{\mathrm{b}}$ & 1.77 \\
Butyrate, mmol & 3.04 & $2.59^{\mathrm{A}}$ & 0.83 \\
Acetate:propionate ratio & $3.33^{\mathrm{A}}$ & $2.61^{\mathrm{B}}$ & 0.19 \\
& & & \\
Molar proportion, $\%$ & & & \\
$\quad$ acetate & 72.78 & 68.81 & \\
$\quad$ propionate & 21.84 & 26.33 & \\
$\quad$ butyrate & 5.38 & 4.86 & 0.23 \\
Ammonia N, mg/100ml & $5.44^{\mathrm{a}}$ & $3.29^{\mathrm{b}}$ & 4.14 \\
Microbial N, mg/100ml & 66.48 & 61.72 & \\
\hline
\end{tabular}

1 values are means for samples taken from 8.00 to $18.00 \mathrm{~h}$ at $2 \mathrm{~h}$ intervals on day 15,18 and 21 of each period

2 standard error of the mean

$\mathrm{a}, \mathrm{b}-\mathrm{P}<0.05 ; \mathrm{A}, \mathrm{B}-\mathrm{P}<0.01$

Ruminal fluid ammonia-N concentration (Table 1) was lower $(\mathrm{P}<0.05)$ for goats infused hainanmycin than infused the solution of ethanol and water. Decreased ruminal ammonia N concentrations (Dinius et al., 1976; Yang and Russell, 1993) could denote suppressed microbial degradation of protein and/or amino acids. This may be due to the ionophore inhibiting the growth of proteolytic ruminal bacteria (Nowbold et al., 1988; Lana and Russell, 1997).

MCP-N concentration in ruminal fluid was not affected by treatment, this was similar to our result in vitro, and also to the report of Dinius et al. (1976). In his experiment, the total number of bacteria and protozoa as determined by direct microscopic count and the number of cellulolytic bacteria also were not affected by monensin.

\section{Changes of nitrogen fractions in duodenal digesta}

Duodenal flow rate was decreased by $15.8 \%(\mathrm{P}<0.05)$ and the DM intake of goats was reduced by $13.7 \%$ in the presence of hainanmycin in the rumen liquid (Table 2). Similar results were reported by Chalupa (1984) with monensin supplementation. Reductions in feed intake were mainly due to promoting an energetically favourable shift in ruminal fermentation, with decreased acetate and increased propionate production. 
TABLE 2

Influence of hainanmycin infusion on each matter contained $\mathrm{N}$ in duodenal digesta of goats

\begin{tabular}{lccc}
\hline & \multicolumn{2}{c}{ Period } & \\
\cline { 2 - 3 } Item & control & experimental & SE' \\
\hline Duodenal flow rate, g/day & $8926.6^{\mathrm{b}}$ & $7520.1^{\mathrm{b}}$ & 549.5 \\
Total N, g/day & 11.21 & 9.33 & 0.59 \\
Ammonia N, g/day & $0.436^{\mathrm{a}}$ & $0.298^{\mathrm{b}}$ & 0.033 \\
Urea N, mg/day & $8.33^{\mathrm{a}}$ & $3.60^{\mathrm{b}}$ & 0.78 \\
Non-ammonia N, g/day & 10.76 & 9.03 & 0.56 \\
Microbial crude protein N, g/day & 2.35 & 1.94 & 0.11 \\
Microbial growth efficiency & 21.01 & 17.44 & 0.87 \\
Protein efficiency, \% & 173.6 & 178.1 & 2.79 \\
\hline
\end{tabular}

1 standard error of the mean

${ }^{2}$ microbial $\mathrm{N} \mathrm{g} / \mathrm{kg}$ organic matter fermented

${ }^{3}$ non-ammonia $\mathrm{N}$ leaving the abomasum $/ \mathrm{N}$ intake

$\mathrm{a}, \mathrm{b}-\mathrm{P}<0.05$

The concentrations of ammonia- $\mathrm{N}$ and urea- $\mathrm{N}$ in digesta were lower $(\mathrm{P}<0.05)$ in experimental than that in control animals (Table 2). Protein efficiency (non-ammonia $\mathrm{N}$ leaving the abomasum/ $\mathrm{N}$ intake) was improved during the hainanmycin infusion period. This may be due to inhibited degradation of dietary protein by microbes, for the microbial growth efficiency was reduced $17.0 \%$ by hainanmycin supplementation. This also implies that the protein bypass $\mathrm{N}$ was increased in view of $\mathrm{N}$ intake (control vs experiment, 136 vs 140\%).

\section{Digestibility of DM, OM, ADF and $N$ in the rumen and total tract}

No evident effects due to hainanmycin infusion were noted for digestion of DM, $\mathrm{ADF}$ and $\mathrm{OM}$ in rumen and total tract (Table 3). This results are consistent with Dinius et al. (1976) and contrast somewhat with the results in vitro (Simpson, 1978; Chalupa, 1980). This is probably the result of increased retention time of both solids and liquids in the rumen (Chalupa, 1984) and/or the cellulolytic bacteria number was not affected by hainanmycin, because Dinius (1976) and Olumeyan et al. (1986) found that the number of cellulolytic bacteria in the rumen was not affected by salinomycin or monensin.

The apparent $\mathrm{N}$ digestibility of total tract (Table 3 ) was significantly enhanced $(\mathrm{P}<0.05)$ in the experiment, this was similar to the reports of Ricke et al. (1984) and Merchen and Berger (1985), who postulated that the increase in apparent $\mathrm{N}$ digestion may occur as a result of an alteration in the relative contribution of microbial and dietary protein reaching the small intestine (microbial protein was presumed 
TABLE 3

Influence of hainanmycin infusion on digestibility in rumen and total tract

\begin{tabular}{|c|c|c|c|}
\hline \multirow[b]{2}{*}{ Item } & \multicolumn{2}{|c|}{ Period } & \multirow[b]{2}{*}{$\mathrm{SE}^{\prime}$} \\
\hline & control & experimental & \\
\hline \multicolumn{4}{|l|}{ Intake, g/day } \\
\hline $\mathrm{DM}$ & 444.8 & 383.9 & 25.2 \\
\hline $\mathrm{OM}$ & 410.3 & 344.0 & 22.2 \\
\hline ADF & 200.6 & 173.2 & 11.4 \\
\hline $\mathrm{N}$ & 6.20 & 5.07 & 0.31 \\
\hline \multicolumn{4}{|c|}{ Leaving abomasum, g/day } \\
\hline $\mathrm{DM}$ & 410.1 & 355.0 & 25.4 \\
\hline $\mathrm{OM}$ & 321.5 & 251.8 & 16.5 \\
\hline ADF & 108.8 & 96.8 & 6.7 \\
\hline Escape feed N, g/day ${ }^{2}$ & 8.41 & 7.09 & 0.52 \\
\hline \multicolumn{4}{|l|}{ Ruminal digestion, $\%$} \\
\hline $\mathrm{DM}$ & 7.76 & 7.53 & 1.45 \\
\hline $\mathrm{OM}$ & 27.26 & 29.17 & 3.73 \\
\hline $\mathrm{ADF}$ & 45.30 & 44.31 & 1.66 \\
\hline Feed N & -35.65 & -36.61 & \\
\hline \multicolumn{4}{|l|}{ Faecal excretion, g/day } \\
\hline DM & 167.3 & 141.4 & 16.1 \\
\hline $\mathrm{OM}$ & 156.9 & 123.3 & 16.5 \\
\hline $\mathrm{ADF}$ & 91.6 & 77.8 & 6.1 \\
\hline $\mathrm{N}$ & 3.34 & 2.30 & 0.26 \\
\hline \multicolumn{4}{|l|}{ Total tract digestion, $\%$} \\
\hline DM & 61.66 & 63.81 & 3.11 \\
\hline OM & 61.82 & 64.73 & 3.38 \\
\hline $\mathrm{ADF}$ & 54.20 & 55.20 & 1.55 \\
\hline $\mathrm{N}$ & $46.08^{a}$ & $56.43^{\mathrm{b}}$ & 3.30 \\
\hline
\end{tabular}

1 standard error of the mean

stat non-ammonia $\mathrm{N}$ leaving the abomasum minus MCP-N

$\mathrm{a}, \mathrm{b}-\mathrm{P}<0.05$

less digestible than ruminal escape feed protein). Total abomasal $\mathrm{N}$ exceeded $\mathrm{N}$ intake in this study (Table 3 ). The more likely cause of this result is that a great deal of endogenous protein has been secreted into digesta when the goats fed only hay.

The general conclusions from this study include: the modifications in the endproducts of ruminal fermentation explain the improvement in feed efficiency and utilization of energy from the diet when the goats were infused hainanmycin, and hainanmycin may spare dietary protein by decreasing ruminal proteolysis. 


\section{REFERENCES}

Armstrong J. P., Spears J. W., 1988. Intravenous administration of ionophore in ruminants: Effects of metabolism independent of the rumen. J. Anim. Sci. 66, 1807-1817

Chany A. L., Marbach E. P., 1962. Modified reagents for determination of urea and ammonia. Clin. Chem. 8, 130

Chalupa W., 1980. Chemical control of rumen microbial metabolism. In: Y. Ruckebuch, P. Thivend (Editors). Digestion physiology and metabolism in ruminants. MTP Press Lid., Lancaster (England), pp. 325

Chalupa W., 1984. Manipulation of rumen fermentation. In: W.Haresign, D.J.A.Cole (Editors). Recent advances in animal nutrition. Butterworths, Boston, pp. 1-4

Chen W., Wolin M. J., 1978. Effect of monensin and lasalocid on the growth of rumen and methane bacteria. Amer. Soc. Microbiol. 78th Annual Meeting Abstract, pp. 88

Dinius D. A., Simpson M. E., Marsh P. B., 1976. Effect of monensin fed with forage on digestion and the ruminal ecosystem of steers. J. Anim. Sci. 42, 229-234

El-Shazly K., Ahmed E. I. A., Naga M. A., Borhami B. E. A., 1976. A colorimetric technique using chromium- ethylenediaminetetroacetate for measuring rumen volume. J. Agri. Sci., Camb. 87 , $369-373$

Lana R. P., Russell J. B., 1997. Effect of forage and monensin on the ruminal fermentation of fistulated cows fed continuously at a constant intake. J. Anim. Sci. 75, 224-229

Makkar H. P. S., Sharma O. P., Dawra R. K., Negis S.. 1982. Simple determination of microbial protein in rumen liquid. J. Dairy Sci. 65, 2170-2173

Martini M., Verita P., Cecchi F., Cianci D., 1996. Monensin sodium use in lambs from the second week of life to slaughter at 105 days. Small Ruminant Res. 20, 1-8

Merchen N. R., Berger L. L., 1985. Effect of Salinomycin level on nutrient digestibility and ruminal characteristics of sheep and feedlot performance of cattle. J. Anim. Sci. 60, 1338-1346

Nowbold C. J., Wallace R. J., Watt N. D., Richardson A. J., 1988. Effect of novel ionophore tetronasin (ICI 139603) on ruminal microorganisms. Appl. Environ. Microbiol. 54, 544-547

Olumeyan D. B., Nagaraja T. G., Miller G. W., Frey R. A., Boyer J. E., 1986. Rumen microbial changes in cattle fed diets with or without salinomycin. Apple. Environ. Microbiol. 51, 340345

Qin Weilin., 1982. Modified determination of rumen volatile fatty acids by gas chromatography. J. Nanging Agric. Univ. 4, 110-112

Ren Mingqiang, Lu Tianshui, Chen Jie, 1996. Effect of polyether ionophore Hainanmycin on rumen metabolism of goat in vitro. Proceedings of 6 th International Conference of Goats, Beijing. pp. $574-577$

Ricke S. C., Berger L. L., van der Aar P. J., Fahey G. C., 1984. Effects of lasalocid and monensin on nutrient digestion, metabolism and rumen characteristics of sheep. J. Anim. Sci. 58, 194202

Russell J. B., Strobel H. J., 1989. Effect of ionophore on ruminal fermentation. Appl. Environ. Microbiol. 55, 1-6

Simpson M. E., 1978. Effect of certain antibiotics in vitro cellulose digestibility and volatile fatty acid (VFA) production by ruminal microorganisms. J. Anim. Sci. 47, Suppl. 1, 429

Van Soest P. J., 1963. Use of detergents in the analysis of fibers feeds. J. Assoc. Off. Agric. Chem. $46,829-835$

Yang C. M. J., Russell J. B., 1993. Effect of monensin on the specific activity of ammonia production by ruminal bacteria and disappearance of amino nitrogen from the rumen. Appl. Environ. Microbiol. 59, 3250-3254 


\section{STRESZCZENIE}

Wplyw nowego polieterowego jonoforu hainanmycyny na trawienie składników pokarmowych i przemiany w żwaczu u kóz

Pięciu kastrowanym samcom - koziołkom, o średniej masie ciała $21,3 \mathrm{~kg}, \mathrm{z}$ przetokami do żwacza i początkowej części dwunastnicy, infundowano do żwacza polieterowy jonofor, hainanmycynę $(0,05 \mathrm{mg} / \mathrm{kg} \mathrm{m.c./dzień)} \mathrm{i} \mathrm{badano} \mathrm{jego} \mathrm{wpływ} \mathrm{na} \mathrm{prcemiany} \mathrm{w} \mathrm{żwaczu} \mathrm{i} \mathrm{strawność} \mathrm{składników}$ pokarmowych w calym przewodzie pokarmowym. Infuzja jonoforu nie wpłynęła na obniżenie sumy lotnych kwasów tłuszczowych w żwaczu, lecz spowodowała zwiększenie $(\mathrm{P}<0,05)$ molamego udziału kwasu propionowego 7. 21,8 do $26,3 \%$, a 7 mnicjszenie $(\mathrm{P}<0,05)$ octowego $7.72,8$ do $68,8 \%$. Stosunek kwasu octowego do propionowego był istotnie mniejszy $(\mathrm{P}<0,01)$ u kóz którym podano jonofor. Poziom $\mathrm{N}$ amonowego $\left(\mathrm{NH}_{3}-\mathrm{N}\right)$ w treści żwacza i dwunastnicy był niższy $(\mathrm{P}<0,05)$ o 39,5 do $16,0 \%$, odpowiednio, a stężenie $\mathrm{N}$-mocznikowego o $56,8 \%(\mathrm{P}<0,05)$ w porównaniu $z$ kontrolą. Infuzja hainanmycyny nie miała wpływu $(P>0,05)$ na pozorną strawnóśc suchej masy, substancji organicznej i ADF w porównaniu $z$ kontrolą, lecz istotnie zwiększyła $(\mathrm{P}<0,05)$ pozorną strawność azotu $\mathrm{z} 46,1$ do $56,4 \%$. 